\title{
The Bumpy Road to Relevance: Croatia, Hungary and Lithuania in Perspective
}

\author{
Gabriella Ilonszki, Davor Boban, and Dangis Gudelis
}

\section{Introduction: Our Questions and Cases}

The emergence and introduction of political science in Europe's new democracies was accepted as a natural given within the context of democratisation; however, how far our selected countries have travelled down the road to relevance- a common theme in the well-established political science communities - remains largely unexplored. This gap needs to be bridged for two main reasons: it seems that now the newcomer countries'

\footnotetext{
G. Ilonszki (禺)

Department of Political Science, Corvinus University of Budapest, Budapest, Hungary

e-mail: gabriella.ilonszki@uni-corvinus.hu

D. Boban

Faculty of Political Science, University of Zagreb, Zagreb, Croatia e-mail: dboban@fpzg.hr

D. Gudelis
}

Faculty of Business and Public Governance, Institute of Public Administration, Mykolas Romeris University, Vilnius, Lithuania

e-mail: dgudel@mruni.eu

(C) The Author(s) 2022

G. Ilonszki, C. Roux (eds.), Opportunities and Challenges for New

and Peripheral Political Science Communities, https://doi.org/10.1007/978-3-030-79054-7_7 
academia face similar challenges and constraints to those in the 'West'; at the same time, however, certain differences concern the institutionalisation of political science, which is still an important, often open question in some of the latecomer political science communities. We shall operationalise relevance on the basis of the 'Western' debate on the relevance issue, while we shall argue that certain additional aspects should also be considered when we explore relevance in our cases. We fundamentally accept that 'Relevance in its narrow sense means addressing issues that lay citizens care about, or should care about.../and/Relevance in its broader sense means bringing new and useful knowledge to a problem that citizens care about' (Gerring, 2015, p. 36). In concrete terms, this means how the profession relates to multiple publics, be they 'normal citizens' listening to a political science commentary, the student body, or decision makers, and the profession appears to be more relevant the more these relationships are widespread and reflexive. It is more difficult to judge relevance in terms of the quality of the knowledge base that the profession creates and provides to such audiences. This chapter will focus on the concrete dimensions of relevance, leaving quality judgements for later research.

We shall develop these different undertakings in regard to the experiences of three new members of the political science community, namely Croatia, Hungary and Lithuania, as they vary in certain important respects. Firstly, does it matter that Croatia has a longer history of political science education; do proto-political studies place political science in a different relevance frame in Croatia than in Hungary or Lithuania? Furthermore, given the different political histories of these countries, we can reasonably assume that their academic communities adopt different perspectives on engagement with the non-academic world. In Croatia, empirical research first emerged in the 1960s, and despite the fluctuating autocratic control of the state and society, some research was conducted about political behaviour and the political system. At the other end of the scale, during the Soviet period in what is now the Lithuanian Republic, a nonindoctrinated approach to the political world was impossible, and anyway there was nobody listening. Hungary could be placed somewhere in between these two, with its 'soft dictatorship' of the 1970s and 1980s (Linz \& Stepan, 1996) during which economists and sociologists were able to impact public discourse based on their empirical research, whereas political science as such was totally absent. We can also expect that the political experiences of the public would affect the way they engage with 
Table 7.1 Some institutional aspects of political science in Croatia, Hungary and Lithuania

\begin{tabular}{|c|c|c|c|c|c|c|}
\hline Country & $\begin{array}{c}\text { Number of } \\
\text { MA } \\
\text { programmes } \\
\text { either as } \\
\text { stand-alone } \\
\text { or joint } \\
\text { programmes } \\
\text { including PS } \\
\text { in } \\
\text { 2019/2020 }\end{array}$ & $\begin{array}{c}\text { Number of } \\
\text { PhD } \\
\text { dissertations } \\
\text { in political } \\
\text { science since } \\
1990\end{array}$ & $\begin{array}{c}\text { Membership } \\
\text { of national } \\
\text { political } \\
\text { science } \\
\text { associations }\end{array}$ & $\begin{array}{l}\text { Number of } \\
\text { political } \\
\text { scientists } \\
\text { identified } \\
\text { for the } \\
\text { purposes of } \\
\text { the COST } \\
\text { framework }^{a}\end{array}$ & $\begin{array}{l}\text { Number of } \\
\text { academic } \\
\text { journals } \\
\text { that } \\
\text { exclusively } \\
\text { publish } \\
\text { political } \\
\text { science } \\
\text { articles }\end{array}$ & $\begin{array}{c}\text { Number } \\
\text { of } \\
\text { academic } \\
\text { journals } \\
\text { that } \\
\text { regularly } \\
\text { publish } \\
\text { political } \\
\text { science } \\
\text { articles }\end{array}$ \\
\hline Croatia & 2 & 164 & 50 & 158 & 3 & 6 \\
\hline Hungary & 8 & 168 & 120 & 233 & 1 & 3 \\
\hline Lithuania & 13 & 89 & 70 & 198 & 6 & 7 \\
\hline
\end{tabular}

${ }^{\mathrm{a}}$ For the research purposes of the COST project, political scientists were defined as follows: those that have a PS PhD, and/or publish in the field of PS, and/or have a PS position at a university or research unit

political science/scientists. Lithuania had to fight for its independence, and organised civil movements played a very important role in this process. Systemic change consisted mainly of an elite compromise in Hungary without any great public engagement, while in Croatia, a painful war of secession was followed initially by a hybrid regime: both situations do not seem to favour political interest on the part of the public.

Furthermore, the country cases reveal the differences in the dimensions of the profession among the countries concerned. Croatia possesses just the one political science institution, the Faculty of Political Science (FPZG) at the University of Zagreb, that offers undergraduate courses and a PhD degree (with two PhD programmes); Hungary offers 8 MA programmes and $6 \mathrm{PhD}$ programmes (either as stand-alone programmes or as joint programmes with other social science fields), while Lithuania boasts five higher education institutions offering $13 \mathrm{MA}$ programmes in the political science field (including public policy, politics and media studies, history and politics ${ }^{1}$ ) together with $2 \mathrm{PhD}$ programmes (see Table 7.1). Finally, it remains to be seen whether the recognised differences between developmental patterns in Northern and Southern Europe (Klingemann, 2008)

\footnotetext{
${ }^{1}$ Public administration study programmes are not included here.
} 
are observable in our cases with regard to how political science is engaged with its broad context.

Table 7.1 shows some aspects of the institutional reality to be found in the three countries concerned, which (among others) will play a role in the bolstering of the relevance of political science in these countries.

With the above questions in mind, in Sect. 2 we shall develop our approach to relevance by focusing on potential institutionalisation differences between East and West, and between our chosen cases. In Sect. 3 we shall analytically deconstruct the concept of relevance through the experiences of the selected countries and present evidence on the usefulness/ applicability of these dimensions. In the conclusive Sect. 4, we aim to establish whether political science can be regarded as relevant in our three countries, and if differences exist, how they can be accounted for. The analysis is based on two sources: the desk top research carried out by the authors, and the country reports and survey results of the COST project.

\section{VARIATIONS: West AND EAST}

The debate over the relevance of political science in the West has been going on as long as political science has existed (Stoker, 2010; Stoker, 2015). From its ethos as being the scientific embodiment and interpreter of modern times - and of democracy in particular - to the more current concerns over its usefulness and practicality, the relevance of political science has often been questioned and analysed. Many years ago, Wilensky argued that what distinguishes a science from a profession is that the latter has clients (Wilensky, 1964, p. 141). This understanding continues to be valid: a profession is expected to provide a well-defined service and engage with the clients, unlike mere disciplines 'which might have clients-if at all—as the whole society', in Wilensky's words.

This relevance debate went through two substantial upheavals in the West, albeit each rooted in different challenges. In the first wave of change during the 1960s and early 1970s, a flourishing profession raised questions about its appointed tasks and missions, which seemed to be changing not only due to the increasing knowledge base and professionalisation of the discipline, but also due to the changing social and political world in which the traditional devotion to democracy seemed outdated (Ricci, 1984). The second sea-change was witnessed in the new millennium, and on this occasion the external driving factors were more explicit. They originated from a variety of different sources: from the introduction of market 
principles in higher education following the growth of the student body, to the introduction of efficiency demands related to the transformation of the university per se. In this regard, Flinders $(2013,2018)$ argues that the demands on the profession have increased so greatly that the question of the relevance gap (that is, political science does not offer enough) should be replaced by the theme of the expectation gap: in an increasingly demanding context, the profession is under stress.

While the two periods of the 'relevance discussion' were characterised either by a focus on normative or pragmatic expectations in regard to the role of political science, they both share the belief that political science should be somehow engaged with the external environment. The normative approach (see, e.g. Eisfeld, 2011) challenges political science on the grounds that it has lost its critical approach to the main problems afflicting our societies, and does not respond to the most pressing problems. The pragmatic approach (see, e.g. Stoker, 2010), on the other hand, claims that a more pragmatic orientation and more practical outcomes are rightly expected from political science.

Both approaches are clearly understood in our countries, and the two focal points of the Western debate, that is the normative and pragmatic approaches, appear in compressed forms in the emerging political science communities of the newcomer states. Moreover, there are two additional dimensions that are important in our specific cases: identity formation, and the achievement and preservation of legitimacy, which relate relevance to the central theme of this volume, namely certain aspects of institutionalisation. This will influence how a profession can and does become relevant.

\subsection{Seeking Identities}

Identity will determine how the profession posits its place, how the profession sees itself and how it acts accordingly - in close interaction with external demands and through internal debate. This identity formation is important as it will impact the way the profession relates to different agents: is it going to be open or is it going to be self-contained? The formation of the profession's identity has clearly followed different trajectories in the countries concerned here.

Discussions about the relevance of political science have been on-going in Croatia for 60 years. During the communist period of political science (1962-1990), these discussions were held by academics and by the ruling 
elite alike. In the view of the country's academics, the identity and autonomy of their discipline was the major concern (see Chap. 4 in this book by Boban \& Stanojević). Although political science institutions were established by the 'regime', political scientists were depicted by one prominent communist politician as 'omniscient ignoramuses', and there was constant fear at the Zagreb Department of Political Science that the Department could be abolished. The discipline also suffered from poor public visibility, as was to be expected in an autocratic regime: political scientists were not called upon by the media to contribute towards open public debate, but continued to live in their own realm cut off from society. The post-1990 years saw more openings for the discipline, but during the first decade of that period the profession was largely engaged with its own development and self-reorganisation, including curriculum change. After 2000, the discipline became to take on its own identity through heated debates held at the Zagreb department. Since then, the presence of political scientists in the media has grown, although a lack of connectivity between political scientists and practitioners remains. Overall, there have been more debates about the internal development of the discipline than about its connections with the general public and the political sphere. The major 'relevance concerns' have regarded the decreasing number of potential students and the problems related to employment opportunities.

The Hungarian trajectory of political science's role and relevance can be divided into three periods. Indeed, the corresponding debate started even before political science had been recognised as an academic discipline. Certain members of Hungary's departments of scientific socialism advocated change in the curriculum, with some limited success at that time. Furthermore, the Association of Political Science (which was founded in the early 1980s) offered an arena for such discussions. In those early years, the main concern was how the profession could manage to stay as far away from politics as possible. This anti-politics concern is indirectly related both to the normative and pragmatic approaches, as defined above, and is rooted in the experience of the communist regime where science could only flourish if it left the political world well alone. During the second period, this self-isolation seemed to diminish, and overall a value-free science got precedence; the issue of relevance has emerged once again as a result of the developments witnessed during the past decade of illiberalism. Political science's standing has been challenged, and the field has become divided: on the one hand there are political scientists who are relevant insofar as they are visible and seem to be well connected to the 
media and the political sphere, and as such they can provide practical advice to those requiring it. On the other hand, however, there are those who remain mainly silent and are expected to meet considerable expectations at university level, as pointed out by Flinders (2018). There can be no doubt that political scientists in Hungary know a lot about relevance, either as a pretext or as illusion, even if they do not talk about it very much.

The issue of political science's relevance has been of critical importance since the very establishment of the discipline in Lithuania during the years of national revival (1988-1990) and following the restoration of the country's independence in 1990. In the autumn of 1988, an open discussion was held on the status and teaching of ideological academic subjects such as the History of the Communist Party of the Soviet Union, and Scientific Communism. Initially, the debate took place in the departments of Vilnius University and among its students; however, within a few months it had spread to all of Lithuania's higher education institutes. Discussions led to the reform of the social sciences and the establishment of political science as an academic discipline, whose curriculum, as the reformers argued, would consist of a mixture of law, civic education and the political history of Lithuania (Krupavičius, 2002, p. 289). Thus, the formation of political science received impetus from the need for a scientific discipline which could study the political processes operating in society and contribute to the process of civic education and democratic transformation broadly perceived by the academic community at that time. The identity of the discipline and its relevance to society remained an important research topic (Krupavičius, 2002, p. 293). For example, the Lithuanian Political Science Association (LPSA) organised a conference on the status of political science in Lithuania in 1999. Other themes dealt with at the LPSA's annual conferences included important issues such as democracy, interest groups, political culture, public administration, security policy, and so on. From 1995 to 2000 public administration departments and study programmes were established in several of Lithuania's universities. Public administration and public policy were perceived as branches of political science, and as such they focused on the improvement of policy-making processes; they were thus perceived as more relevant than other branches of 'pure' political science. At the same time, as Lithuanian political scientists, especially those of the younger generation, became familiar with political science research in the West, thus advocating value-free form of political science also found its place in academia. However, the view that political science should somehow contribute 
towards society and improve political processes still prevails among Lithuanian political scientists, and their role and mission as such are recognised by the country's media, political parties and government. Political scientists regularly comment on political events (elections, etc.) in the media, work for 'think tanks' and consultancy firms doing policy-oriented research and take part in working groups established by government institutions. A good example of the relevance of political science in Lithuania is the ongoing project 'ManoBalsas.lt' (My Vote), ${ }^{2}$ which was started in 2008 by a team of political scientists from various Lithuanian universities, who developed an online-based tool for rational voting. The tool gathers responses from politicians and voters to questions of importance to society, and measures the correspondence of their political beliefs, thus providing support for the electoral choice.

This brief overview shows that the role of political science, and its engagement with different actors, has been an issue in our countries. These considerations concerning the relevance of the profession appear to be closely connected to the identity aspects of institutionalisation. Both the normative and the pragmatic approaches have been adopted at different moments in time, and to different degrees, in the countries concerned. In Croatia the debate is still on-going, in Hungary it has re-emerged, whereas in Lithuania, it has been settled for good. Generational change (particularly in Croatia and Hungary) and political change (in Hungary) have a clear impact on this. In Hungary, a divided profession is also divided on the question of which form of relevance it is focused on (the normative or the pragmatic). In Lithuania the trend reveals the profession's tendency towards pragmatism. In Croatia, a small, self-contained political science community is mainly concerned with the pragmatic aspects of engagement, particularly in the realm of education, in order to gain and maintain legitimacy.

\subsection{Legitimacy in Question}

While the development of political science's identity will influence the profession's normative and pragmatic approaches to relevance, and its engagement with diverse actors, in the case of the more recently established political science communities the legitimacy question may also be decisive. Only a legitimate discipline can make its voice heard both socially and politically, that is, be seen as relevant. Thus the formal first steps like policy decisions and legal documents, legitimising the profession, were of

\footnotetext{
${ }^{2}$ Mano balsas Lt, https://www.manobalsas.lt/index/index.php.
} 
fundamental importance. However, legitimacy also needs to be preserved, and this shall be the second aspect examined in this section.

The three main institutions in Croatia dealing with the regulation of science and higher education are the Ministry of Science, the Agency for Science and Higher Education (AZVO) - an independent body in charge of accreditation and re-accreditation-and the universities themselves. Unlike in Hungary and Lithuania, the discipline has been called 'political science' in Croatia (to be precise, political sciences or politologijapolitology $)^{3}$ since its inception in 1962, and has remained accepted under this name during the post-communist period, which differentiates it somewhat from the other two cases. The FPZG has sole authority to grant BA, $\mathrm{MA}$ and $\mathrm{PhD}$ degrees, and also enjoys the exclusive right to organise the process of academic promotion for all political scientists in the country.

In Hungary, the legitimacy of the profession was established soon after the democratic transition. The Hungarian Accreditation Committee (MAB), initially set up in 1992 before taking its current form in 1994, was an independent (non-governmental) body comprising the leading members of academia. The MAB was responsible for formulating criteria and accrediting all academic programs and professorial nominations. The process was highly competitive, and several institutions-including established large universities - tried to launch political science programmes which were not always successful, were accepted temporarily, or were indeed rejected and the whole process has/had to be started again (Rébay \& Kozma, 2005).

In Lithuania, the accreditation of study programs was not introduced until 2002; however, several legislative acts had contributed towards establishing a system of accreditation before then. Government provisions introduced in 1993 regulated the control and certification of higher education institutions, and in order for such an institution to be certified, its study programmes, study methods and measures had to meet the established requirements. The provisions in question established that the list of study areas and fields proposed by a higher education institution had to be approved by the Conference of Rectors of Lithuanian Higher Education Institutions and by the Research Council of Lithuania. The same regulations stipulated that every five years, and if necessary more often, the

\footnotetext{
${ }^{3}$ This word is not commonly used in English, although Philippe Schmitter does use it in one of his papers. https://www.eui.eu/Documents/DepartmentsCentres/SPS/Profiles/ Schmitter/Politics-as-a-science.pdf.
} 
Government of the Republic of Lithuania was to form an expert commission to assess the level of higher education in the country. The first commission tasked with monitoring performance was formed by the Lithuanian Government's Decree of October 20, 1994. At that time, higher education institutions' performance in the field of social sciences was evaluated as one of the lowest of all scientific fields.

Very similar patterns are observable in all three countries, which is not surprising given that the process was conducted in accordance with international standards and adaptation/adjustment requirements. The only real difference is the time dynamics of implementation of such provisions: they were introduced early and quickly in Hungary, but more slowly and following a more complex procedure in Lithuania; Croatia, on the other hand, saw a combination of continuity and new institutional requirements.

In the longer term, the legitimacy of a discipline is not built on formallegal requirements only. Its status may well be confirmed or challenged by simple things, like the remarks of a decision-maker such as those of the Croatian communist party leader mentioned above. To preserve legitimacy, performance-related factors have to be taken into account, (even though expectations can be forcibly set by external actors), as formulated in the 'Western debate'. On the other hand, the legitimacy of the profession may be challenged on normative grounds. Whichever of the two represents the main form of pressure-(abusive) external expectations or the aura of unsafety - they could fail to sustain the relevance of the discipline. We would argue that as the profession develops, the legal component of said recognition should decrease, while evaluative and supportive measures should increase, as clear signs of the discipline's continued legitimacy. In Croatia, the process of accreditation is conducted regularly every five or six years at university departments, to ensure the quality of research and education. So far, all re-accreditation of political science programmes in Croatia has taken place at the FPZG. There have been attempts to establish one BA and one MA study programme in political science at two other universities, but these have proven unsuccessful. At the time of writing this chapter the most recent accreditation is just going on. The former re-accreditation procedure conducted at the FPZG was in 2014 and resulted in the reduction in student numbers, as the accreditation criteria required the FPZG to have a student-staff ratio of less than 30:1. In Lithuania, the newly established Centre of Quality Assessment in Higher 
Education $^{4}$ (1996) was tasked with evaluating the country's higher education institutions, and the evaluation process was subsequently developed in several stages. The system for the evaluation of study programmes was completed in 2002, with the establishment of the procedure for the accreditation of higher education study programmes on the basis of their assessment. ${ }^{5}$ Political science programmes at Vilnius University, Klaipeda University and Vytautas Magnus University were evaluated by external experts from the Center of Quality Assessment in Higher Education and received their official accreditation in 2008. ${ }^{6}$ Another step towards strengthening the profession's legitimacy was taken with the official recognition of political science as a separate study area within the broader field of the social sciences. The legislation approving the classification of academic disciplines and sub-disciplines, including political science, ${ }^{7}$ set out a list of sub-disciplines comprised within the political science field, including Political Theory, Public Policy and Administration, European Union Studies, Regional Policy Studies, International Relations, Comparative Politics, and Military and Peace Studies. A few years later, a team of experts (political scientists from Lithuania's major universities) prepared a description of political science as an area of study, setting out requirements for study programmes in this area, and this was subsequently approved by the Center of Quality Assessment in Higher Education (2014). ${ }^{8}$ Contrary to the aforementioned patterns of increased quality

\footnotetext{
${ }^{4}$ The Center of Quality Assessment in Higher Education under the Ministry of Higher Education and Science as the major government institution responsible for quality assessment of studies and recognition of qualifications was established in 1995.

${ }^{5}$ LR švietimo ir mokslo ministro ịsakymas Nr. 1194 Dẻl Sprendimụ dèl ịvertintụ aukštojo mokslo studijų programų priemimo tvarkos patvirtinimo [Order of the Minister of Higher Education and Science of the Republic of Lithuania No.1194 on Approval of Adoption Procedure of Decisions on Evaluated Higher Education Study Programs], 2001-08-13, Valstybès žinios, 2001-08-22, Nr. 72-2550.

${ }^{6}$ LR švietimo ir mokslo ministro įsakymas Nr. İSAK-570 Dėl Aukštojo mokslo studijų programų akreditavimo [Order of the Minister of Higher Education and Science of the Republic of Lithuania No.1194 on Accreditation of Higher Education Study Programs], 2008-03-03, Valstybės žinios, 2008-03-20, Nr. 33-1201.

${ }^{7}$ LR švietimo ir mokslo ministro ịsakymas Nr. V-222 Dẻl studijų kryptis sudarančių šakụ sąrašo patvirtinimo [Order of the Minister of Higher Education and Science of the Republic of Lithuania No.222 on Approval of the List of Branches within Study Areas], 2010-02-19, Valstybès žinios, 2010-02-23, Nr. 22-1054.

${ }^{8}$ Politikos mokslų krypties aprašas [The Description of area of political science studies], Vilnius: SKVC, 2014. politica https://www.skvc.lt/uploads/documents/files/ Kokyb\%C4\%97s\%20u\%C5\%BEtikrinimas/krypciu_aprasai/Politikos\%20mokslu\%20studiju\%20krypties\%20aprasas.pdf.
} 
control, and in Lithuania in particular of nuanced prescriptions, Hungary saw growing government influence open the way for less clearly outlined policies after 2010. The Hungarian Accreditation Committee (MAB) has been reorganised-and is now dominated by government nominees. The minister in charge of the Government Education Office $(\mathrm{OH})$ often overturns even the decisions taken by the new MAB. In fact, the MAB's membership of the European Association for Quality Assurance of Higher Education (ENQA) has been temporarily rescinded due to concerns over its independence and funding. While external evaluation continues, higher education institutions need to put their own quality insurance schemes in place, which is concerning given that universities are constrained by the government's policy decisions.

While all the three countries in question have been members of the ENQA, it would seem that membership conceals a variety of different accreditation practices. In Hungary, early and strict accreditation criteria are being replaced by opaque, politically motivated provisions. Accreditation in Croatia is independent from governmental influence, and the AZVO is responsible for the whole process, including the final recommendation made by the Minister of Science or by her/his deputy. In Lithuania, the higher education evaluation and accreditation system is well developed and is not constrained by government.

The legitimacy of a profession is re-confirmed by the authorities by means of several measures, not only the legal-official processes. One seemingly strange, but fundamental, aspect is the allocation of public funding. While the shortage of research funding is generalised, there are nevertheless considerable differences among the three countries. There is almost no research money available in Croatia, with the sum of 200-300 euros provided for a handful of research projects by the University of Zagreb. In Hungary the flagship national research foundation tends to finance 2 or 3 political science research projects per year (with an average budget of around 50,000 euro for each 3- or 4-year project), and this has not risen at all over the past two decades. In Lithuania, on the contrary, since 2009 the country's Research Council has been implementing the programmebased competitive funding of research, and each year it issues more than 30 calls for the submission of project proposals from a list of 40 national and international programmes on average. The funding portfolio includes top-down schemes with pre-defined research topics, such as the National 
Research Programs, as well as bottom-up schemes. Research projects in the field of political science may receive funding from diverse national research programmes, like 'Welfare Society', the 'Lithuanistics development' program, 'Researchers teams projects', the 'Lithuanian-Polish international cooperation program DAINA, 'Needs-based research projects', and others. For instance, during the period 2015-2020 the Research Council of Lithuania has allocated around 8,300,000 euros for 90 'Research team projects' in the humanities and social sciences. Of these, 10 projects have been in the field of political science (as a main or secondary research field), accounting for an $8.3 \%$ share (around 700,000 euros) of the total funding provided for this particular research programme (considered to be the most prestigious such programme and the one giving the highest quality research results and resulting in the best academic publications). Consequently, political science research has quite a good chance of obtaining funding, as many of these programmes are in some way related to policy-oriented research. However, the competitive research funding system is a complementary measure, and does not ensure security for the profession, since average salaries for teaching and research staff in Lithuanian universities are among the lowest in Europe.$^{10}$ The three countries' research-funding capacities depend on several factors; consequently, no automatic conclusions may be drawn about how legitimate a profession is seen as, on this basis. Still, the differences are clear for all to see and funding shortage is visible, particularly in Croatia.

\section{Relevance: Concepts, Evidence and Attitudes}

Having seen the contextual differences and the legitimacy-based foundations of the profession, in this section we shall (de)construct and operationalise the relevance concept, largely building on Flinders' (2013) approach. The three dimensions to be taken into consideration in doing so are related to three potential fields of engagement, which we shall call: knowledge provision, social presence and practical impact. We are going to

\footnotetext{
${ }^{9}$ https://www.lmt.lt/en/science-policy-implementation/lituanistics-development/2551.

${ }^{10}$ Lietuvos ūkio sektorių finansavimo po $2020 \mathrm{~m}$. vertinimas: Mokslas, technologijos ir inovacijos [Financing of Lithuanian economic sectors after the 2020 Assessment: Science, Technology and Innovation], 2019, p. 8, http://www.strukturiniaifondai. lt/lt//dokumentai//lietuvos-ukio-sektoriu-finansavimo-po-2020-metu-vertinimas / mokslas-technologijos-ir-inovacijos-5-priedas?type=versions.
} 
develop some measures of the three and also examine the attitudes of the three countries' political science communities to such fields of engagement.

When considering the question of knowledge provision, we shall identify what kind of political science we provide to our students, and the way that the curriculum has developed. Has the curriculum become more pragmatic? Are there courses that reflect on the problems of our time and of our countries? Similar questions can be raised when identifying $\mathrm{PhD}$ topics and observing the profile of the national political science journal or of other publications. Social presence will describe engagement with the public, and how political science acts in this realm. Are research findings divulged to a general audience, including the activities of political science associations. Practical impact will reveal the degree of engagement with decision-makers. How widespread and acknowledged are these practical activities?

In keeping with the above framework, we shall examine the three aspects of relevance below. Before doing so, however, it is interesting to examine how the respondents in the aforementioned COST project survey conducted in 2018, indicated their level of agreement with the statements concerning the relevance of the discipline (see Table 7.2).

Table 7.2 Agreement with the statements concerning the relevance of political science

\begin{tabular}{|c|c|c|c|c|c|c|c|c|}
\hline \multirow[t]{2}{*}{ Country } & \multicolumn{2}{|c|}{ Croatia } & \multicolumn{2}{|c|}{ Hungary } & \multicolumn{2}{|c|}{ Lithuania } & \multicolumn{2}{|c|}{ Total } \\
\hline & Mean & $N$ & Mean & $N$ & Mean & $N$ & Mean & $N$ \\
\hline $\begin{array}{l}\text { Political scientists should } \\
\text { provide evidence-based } \\
\text { knowledge and expertise } \\
\text { outside academia, but not } \\
\text { be directly involved in } \\
\text { policy-making. }\end{array}$ & 2.23 & 22 & 2.92 & 66 & 3.07 & 44 & 2.86 & 132 \\
\hline $\begin{array}{l}\text { Political scientists have a } \\
\text { professional obligation to } \\
\text { engage in public debate. }\end{array}$ & 3.48 & 23 & 2.61 & 66 & 3.07 & 46 & 2.91 & 135 \\
\hline $\begin{array}{l}\text { Political scientists should } \\
\text { become involved in policy } \\
\text { making. }\end{array}$ & 3.52 & 23 & 2.82 & 66 & 3.15 & 46 & 3.05 & 135 \\
\hline $\begin{array}{l}\text { Political scientists should } \\
\text { refrain from direct } \\
\text { engagement with policy } \\
\text { actors. }\end{array}$ & 1.50 & 22 & 1.91 & 65 & 1.77 & 44 & 1.79 & 131 \\
\hline
\end{tabular}

Source: PROSEPS Q 14 
The responses were coded using the 4-item Likert scale (from 4-fully agree to 1 -fully disagree). The table presents mean values calculated for the answers given by respondents from Croatia, Hungary and Lithuania. The answers can be connected to the relevance frame as described above. The statement 'Political scientists should provide evidence-based knowledge and expertise outside academia, but not be directly involved in policy-making' refers to the 'Knowledge provision' dimension. This statement resulted in the highest level of agreement among Lithuanian political scientists, while fewer of their colleagues from Croatia and Hungary agreed with it. The level of agreement with the second statement 'Political scientists have a professional obligation to engage in public debate' measures 'Active presence'. The political scientists from Croatia expressed the strongest support for this statement, while Hungarian political scientists were the least supportive. The statement 'Political scientists should become involved in policy making' could be associated with the 'Practical impact' of relevance. The survey revealed that respondents from Croatia were the ones who agreed with this statement the most, while their colleagues from Lithuania were less supportive, and Hungary's political scientists were even less so. The fourth statement is directly related to the third: 'Political scientists should refrain from direct engagement with policy actors' (this fourth statement being formulated in the opposite wayi.e. negatively - to the other three statements). This was met by the lowest level of agreement from all three groups concerned (the differences between the groups were not statistically significant), thus confirming their support for policy engagement, subject to the aforementioned country differences. There seems to be support for being present in the public realm and also in political practice, albeit with clear country differences; Hungarian respondents were less open to such involvement than their Lithuanian and Croatian counterparts.

After viewing the attitudes of the responding political scientists, we shall examine the three aspects of relevance, and offer some concrete evidence in addition to occasional reference to the attitudes of political scientists.

\subsection{Knowledge Provision}

As specified above, we shall first examine how we are to establish whether political science creates and provides knowledge that can be regarded as relevant, as this will depend 'upon judgements about which directions will provide the greatest value-added for society' (Gerring, 2015, p. 47). 
Although we are not qualified to make such a judgment here, on the basis of an analysis of external demand and the considerations of the political science community, we shall try to establish the potential relevance of knowledge provision.

a) How can education be relevant?

A first, albeit indirect, measure is the number students, since it is one of the things that shows whether society 'accepts' political science and finds the knowledge provided by this field useful or/and interesting, or indeed whether the labour market opportunities for political scientists are promising or not. Are we going forwards or backwards in this regard?

Table 7.3 includes the number of students enrolled in political science programmes at BA and MA levels in 2012 and 2019, including all programmes bearing the term 'political science' (or 'politics', 'policy', 'public governance' $)^{11}$ in their title. The COST data revealed that the decline of the student body is most clearly evident in the CEE countries, and our countries are no exception in this respect.

In Hungary, there has been a decline in student numbers throughout the entire higher education system, political science being no exception to the rule. In 2020, the overall number of applicants to higher education institutions was one-third less than it had been in 2019, which is similar to the trend in political science. The proportion of enrolment in MA programmes compared to that in BA programmes fell from around $40 \%$ in 2012 to around $20 \%$ in 2019. There are accredited political science programmes that are depopulated, as no students apply for admission. In

Table 7.3 Number of students enrolled in political science programmes at BA and MA levels

\begin{tabular}{lcccc}
\hline Country & BA 2012 & MA 2012 & BA 2019 & MA 2019 \\
\hline Croatia & 678 & 182 & 499 & 115 \\
Hungary & 267 & 109 & 372 & 76 \\
Lithuania & 679 & 314 & 331 & 175 \\
\hline
\end{tabular}

Source: PROSEPS database

\footnotetext{
${ }^{11}$ Students enrolled in public administration study programmes are not included in the numbers.
} 
Croatia, the abolishment of tuition fees ten years ago prevented most faculties from earning income from this source, and consequently there was a decline in the number of students particularly because accreditation prescribes a rigid student-professor ratio, as mentioned above. This has a positive impact on the quality of education, but engenders other problems. More specifically, the decreasing number of BA students over the years has produced a smaller pool of potential MA-level candidates. Moreover, BA graduates now can study for their MA at other universities in Europe. Finally, the decision of the FPZG whereby only students with a BA in political science can enrol in a MA programme in political science, has also resulted in a smaller number of potential MA students. In Lithuania, the overall number of students, as well as the number of political science students at both BA and MA levels, has also been decreasing for demographic reasons such as lower birth rates and emigration. The numbers of students enrolled in BA and MA programmes fell by nearly one half between 2012 and 2019. The reduction in the numbers of students enrolled in public administration programmes has been even more dramatic: those enrolled in public administration BA programmes decreased by almost 90\%, from 666 in 2012 to 73 in 2019; and the numbers of students enrolled in MA programmes fell by two-thirds, from 297 in 2012 to 101 in 2019 . Universities had to adapt: certain study programmes had to be closed; the numbers of teaching staff in political science departments had to be reduced, thus increasing the insecurity of the profession. The correlation between the BA and MA figures in particular reveals the recognised prospects of the discipline-indeed its relevance in the eyes of the students, and potentially their families who even if they do not have to pay tuition fees still have to support the students financially. In Lithuania (as opposed to Hungary and Croatia), MA programmes in political science (and public administration) have become more popular than BA studies, as they attract not only graduates from high schools but also professionals with job experience (civil servants). This represents relevance per se.

In addition to demographic trends and government policy, we should also consider the possibility that decreasing numbers might be the result of declining interest: what does political science offer to students? What kind of subjects are included in the curriculum? Have there been any changes in this regard? In Hungary, constant attempts were made to develop the programmes' practical aspects so as to ensure better job opportunities for students, through courses in methodology, public relations and political communication. Nevertheless, methodology courses 
are not strongly present in most programmes, but compared to the early years there has been tempering of the political philosophy approach to courses and to the curriculum as a whole (Arató \& Tóth, 2010). A more empirical form of political science has clearly emerged. As political science departments and programmes are relatively small in terms of the academic staff employed, there is a tendency to establish larger units incorporating several previously separate units/programmes. While a broader knowledge base might increase the decisional freedom of students, as they can select from a larger range of courses, there are concerns that the profile and identity of political science will diminish within such larger units.

In Croatia, given the single institution pragmatic considerations (the availability of teaching staff for each field) and functional ones (ensuring that recently qualified political scientists with BA and MA degrees can find jobs) have been carefully balanced. With the advent of the Bologna process, new courses were introduced in all areas of political science, and new staff have been hired possessing the expertise required to establish courses that had not previously existed. The diversification of the subjects on offer gives students a wider choice of courses and specialisation, depending on their interests. This also renders the discipline more recognisable among the other social sciences and humanities. The political science curriculum has changed since the beginning of the Bologna process, with the introduction of new courses in all major fields covered by the discipline, particularly in area studies, EU studies and studies on democracy. This represents a radical departure from the normative approach to the curriculum prior to 2000 , when there were a great many courses in political philosophy and theory.

In Lithuania, the curriculum was impacted by the national higher education reform implemented in 2010-2012. The reform created a new system for the allocation of funding to universities, based on the so-called student's basket principle, that is, with the best students receiving full state funding for their studies in their chosen field. The reform also increased the autonomy of universities by implementing changes in university governance such as the election of university rectors by university boards comprising representatives of various stakeholder groups, and greater discretion in regard to the use of university property. These market-based institutional changes strengthened the competitive environment within the higher education sector, creating incentives for universities to treat students as their customers, and to invest in advertising and other marketing activities in order to attract them. Thus, new study programmes were 
created with catchy titles, and the curricula of existing study programmes were transformed in order to meet perceived student needs. On the one hand this trend had a negative effect, especially on the quality of higher education in the social sciences, as universities had an incentive to drop difficult subjects such as statistical analysis in order to ensure greater student satisfaction. On the other hand, it contributed to the increased internationalisation of the study process as universities, due to diminishing national demand, were forced to look for ways of attracting foreign students (e.g. by creating joint study programmes with foreign universities or by offering their own study programmes or separate subjects in English).

Lithuania has a long tradition of cooperation between departments of political science and politicians and government officials, in regard to both research and education, especially among those universities located in the capital city. When the departments organise conferences and other events (e.g. roundtable discussions on relevant policy issues), politicians and government officials (ministers, deputy ministers, civil servants, etc.) are also invited as presenters or participants. Professors also sometimes invite politicians or representatives from the government to give lectures in their own courses. In Croatia, guest lectures are occasionally delivered by foreign diplomats, although rarely by politicians. The professors themselves are not particularly willing to invite politicians to give lectures since they believe that politicians' knowledge of politics is of a limited quality, whereas their practical knowledge and experience is not taken into account. In Hungary, practice-oriented events (meetings with, and learning from, politicians and men/women of practice) have generally disappeared from the sphere of university education over the past decade. It has become increasingly difficult to reach out to politicians, and even to carry out research that would involve their input. This is a major relevance issue: politicians' knowledge and its critical evaluation cannot be channelled into research and education.

Despite achievements such as the stabilisation of BA and MA programmes, the profession continues to be beset by problems relating to the issue of relevance: decreasing student numbers seems to be a common problem; the increasing incorporation of political science into larger programmes could raise identity concerns, although as mentioned above it does not necessarily imply the diminishing relevance of the field. The marketisation of higher education studies and the introduction of certain fashionable and 'superficially relevant' programmes would negatively affect the quality of education. 
Similar patterns prevail in all three countries with regard to $\mathrm{PhD}$ programs, although this is not directly related to education as such, but concerns the development of the profession. Lithuania's first political science $\mathrm{PhD}$ programme was set up in 1992, the first one established in Hungary dates from 1993. In Croatia, the first Bologna-type programme started in 2010 in comparative fields followed through by other sub-fields in 2010 . Table 7.1 shows the number of $\mathrm{PhD}$ degrees which has been characterised by two important features: on the one hand, $\mathrm{PhD}$ dissertations largely concern important, or should we say, topical themes, which is a sign of professional relevance, with a proliferation of international and EU topics, together with the appearance of diverse policy themes; on the other hand, most $\mathrm{PhD}$ graduates have not been able to find a position in academia, although they can easily find employment in bureaucracy, government think tanks, or NGOs.

\subsection{Publication Performance}

The matter of publication performance is linked to our question in two respects: publications offer the profession the opportunity to prove that it is very much present, that it delivers and thus deserves its place in academia. One survey has found that the majority of university academics are more interested in research work than in teaching (Teichler, 2014, Table 7.2); thus, the expectation to publish seems to be correlated to the research-orientated views of academics themselves. At the same time, a substantial number of those working in academia do not publish at all (Kwiek, 2015) and it is often difficult to reconcile teaching and research (Turk \& Ledić, 2016). The COST survey portrays a more nuanced picture.

As Table 7.4 shows, a large proportion of respondents (around 40-50 per cent) have never published anything jointly with an international coauthor, while a smaller, but still relatively significant, proportion (oneeighth in Croatia and Lithuania and around one-third in Hungary) reported that they had never published in a peer-reviewed international journal. These figures that relate to the international component of relevance, and given the increasing international publication trends (Jokić et al., 2019), are significant. ${ }^{12}$ While in Hungary the entire academic sector has seen a decline in publications (Polónyi, 2018), a more recent study

\footnotetext{
${ }^{12}$ We would like to thank Stjepan Mateljan from Institute for Social Research in Zagreb who introduced us to the co-authorship network connecting our three countries. Although
} 
Table 7.4 Regarding your publishing record, please indicate whether in the last three years you have published

\begin{tabular}{|c|c|c|c|c|c|}
\hline & & & Croatia & Hungary & Lithuania \\
\hline \multirow{4}{*}{$\begin{array}{l}\text { Articles in peer-reviewed } \\
\text { international journals }\end{array}$} & None & $\%$ within & $12.5 \%$ & $27.3 \%$ & $13.0 \%$ \\
\hline & $\begin{array}{l}\text { At least } \\
\text { once }\end{array}$ & Country & $37.5 \%$ & $39.4 \%$ & $54.3 \%$ \\
\hline & $\begin{array}{l}\text { Three } \\
\text { or more }\end{array}$ & & $50.0 \%$ & $33.3 \%$ & $32.6 \%$ \\
\hline & & $N$ & 24 & 66 & 46 \\
\hline \multirow{4}{*}{$\begin{array}{l}\text { Chapters in edited books } \\
\text { published by international } \\
\text { publishing houses }\end{array}$} & None & $\%$ within & $37.5 \%$ & $34.4 \%$ & $32.6 \%$ \\
\hline & $\begin{array}{l}\text { At least } \\
\text { once }\end{array}$ & Country & $29.2 \%$ & $46.9 \%$ & $53.5 \%$ \\
\hline & $\begin{array}{l}\text { Three } \\
\text { or more }\end{array}$ & & $33.3 \%$ & $18.8 \%$ & $14.0 \%$ \\
\hline & & $N$ & 24 & 64 & 43 \\
\hline \multirow{4}{*}{$\begin{array}{l}\text { Monographs published by } \\
\text { international publishing houses }\end{array}$} & None & $\%$ within & $79.2 \%$ & $92.3 \%$ & $85.4 \%$ \\
\hline & $\begin{array}{l}\text { At least } \\
\text { once }\end{array}$ & Country & $20.8 \%$ & $7.7 \%$ & $4.9 \%$ \\
\hline & $\begin{array}{l}\text { Three } \\
\text { or more }\end{array}$ & & $0.0 \%$ & $0.0 \%$ & $9.8 \%$ \\
\hline & & $N$ & 24 & 65 & 41 \\
\hline \multirow{4}{*}{$\begin{array}{l}\text { Published with international } \\
\text { co-authors }\end{array}$} & None & $\%$ within & $39.1 \%$ & $52.3 \%$ & $45.5 \%$ \\
\hline & $\begin{array}{l}\text { At least } \\
\text { once }\end{array}$ & Country & $43.5 \%$ & $33.8 \%$ & $47.7 \%$ \\
\hline & $\begin{array}{l}\text { Three } \\
\text { or more }\end{array}$ & & $17.4 \%$ & $13.8 \%$ & $6.8 \%$ \\
\hline & & $N$ & 23 & 65 & 44 \\
\hline
\end{tabular}

Source: PROSEPS Qs. 26 and 28

of political science publication trends provides a more positive picture, with a substantial increase observed over the past three decades (Molnár \& Ilonszki, 2021). The journal of the Hungarian Political Science Association-Politikatudományi Szemle-has been the profession's flagship publication since its foundation in 1992 and has become a quality journal that uses a double-blind review procedure. It seems that the 'relevance debate' was more often covered by the journal during its early years, and mainly concerned the profession, its relation to politics, or the quality and focus of publications. For example, the official report of the

this network has yet to attract any significant number of members, this chapter will certainly contribute towards remedying this situation. 
Political Science Committee of the Hungarian Academy of Sciences warmly welcomed the fact that publications were beginning to move away from public journalism to a more science-based focus (Balogh, 1999). There is no systematic information available regarding the readership of the journal outside of the political science academic community, but it may extend beyond that community. Although mere examples cannot represent scientific truth, one of this chapter's co-authors can confirm that after publishing an article on ministers she got a letter from a former minister disagreeing with the categories described in the article, including his own alleged position. The never-ending argument among political scientists about the language used in academic journals is a recurrent one: the argument is that the Hungarian language used in the journal should be maintained in order to ensure its local connectedness.

In Croatia, the first political science journal 'Politička misao' (Political Thought) was founded in 1964, and is published by the FPZG. During the communist period, the Marxist theoretical, critical and normative approaches prevailed. After 1990, and following changes to the FPZG staff's expertise, the profile of the journal improved and the peer review process is now expected to be similar to that of the Annals (published by the Croatian Political Science Association since 2004, and also connected with the FPZG in terms of its editorial staff). Until a few years ago, the contributors to Politička misao were mostly professors at the FPZG. Since new rules governing academic staff promotion discourage publication in so-called 'in-house publications', the FPZG's professors have generally refrained from publishing in these 'in-house journals', and have thus been encouraged to publish elsewhere, including in foreign journals. Since 2016, Politička misao has published four numbers per year: two or three numbers in the Croatian, Serbian, Bosnian and Montenegrin languages (depending on the native language of the author); and one or two issues in English. There is also an academic journal-Političke Perspektive (Political Perspectives)—which is jointly published by the FPZG, the Faculty of Political Science of Belgrade University and the Political Science Association of Serbia.

In Lithuania, the first issue of the political science journal Politika (later renamed Politologija) was published in 1989. Since 1992, 'Politologija' has been affiliated to the Lithuanian Political Science Association and published by the Institute of International Relations and Political Science (IIRPS) at Vilnius University. Until 2017 'Politologija' had been publishing articles in Lithuanian only. Other important political science journals 
include 'Public Policy and Administration', 'Lithuanian Foreign Policy Review', 'Baltic Journal of Law and Politics', 'Agora' and 'Politikos mokslų almanachas'. The journal 'Public Policy and Administration', founded jointly by Mykolas Romeris University and Kaunas University of Technology in 2002, has the highest SJR index (0.409) of all these journals and is included in the Scopus database. Furthermore, political science articles are occasionally published in the journals of other social science fields, such as 'Transformations in Business and Economics', 'Creativity Studies', 'Information Sciences', 'Philosophy \& Sociology'. As in the other two countries, the performance evaluation system which is used to regularly assess the research performance of individual scientists and academic units, encourages political scientists to publish.

\subsection{Active Social Presence}

Several questions in the Survey focus on political scientists' perceptions of the connections between the profession and the public, and the ways in which they try to connect to a broader public. It is not easy to account for the potential differences. For example, on a scale of 0 to 10 , where a value of 0 means that 'the participation of political scientists in public debate is not recognised at all for career advancement', while a value of 10 means that it is 'very much recognised and relevant' (COST survey question No. 6), the lowest score, 3.88 , is that recorded in Croatia while the highest is that of Lithuania with a value of 6.28 , while Hungary is ranked in between, at 4.95. It would seem that the academic-university context (in terms of the perceived importance of engaging with the public) is a clear incentive to participation in public debate. At the same time, there is no substantial difference between the countries in terms of respondents' acceptance of the fact that an active social presence is part of an academic's professional duties. In response to the statement 'Political scientists should engage in public debate since this is part of their role as social scientists', average agreement measured on a scale of from 1 (fully disagree) to 4 (fully agree) ranges from 3.15 in Hungary to 3.63 in Croatia.

Table 7.5 indicates the types and the frequency of such engagement. The frequency of engagement was measured on a scale from 1 (less than once a year) to 5 (once a week). The table shows that in all three countries, the mean response to the statements about contributions to TV programmes, radio broadcasts, newspapers and magazines (including 
Table 7.5 Please specify the average frequency of

\begin{tabular}{|c|c|c|c|c|c|c|c|c|}
\hline \multirow[t]{2}{*}{ Country } & \multicolumn{2}{|c|}{ Croatia } & \multicolumn{2}{|c|}{ Hungary } & \multicolumn{2}{|c|}{ Lithuania } & \multicolumn{2}{|c|}{ Total } \\
\hline & Mean & $N$ & Mean & $N$ & Mean & $N$ & Mean & $N$ \\
\hline $\begin{array}{l}\text { Your interventions on TV programmes } \\
\text { related to political issues (during the last } \\
\text { three years) }\end{array}$ & 2.93 & 14 & 3.20 & 10 & 2.92 & 26 & 2.98 & 50 \\
\hline $\begin{array}{l}\text { Your contributions to radio broadcasts } \\
\text { related to political issues during the last } \\
\text { three years }\end{array}$ & 2.50 & 14 & 2.69 & 16 & 2.67 & 30 & 2.63 & 60 \\
\hline $\begin{array}{l}\text { Your contributions related to political } \\
\text { issues in newspapers, magazines (including } \\
\text { electronic ones and news portals) during } \\
\text { the last three years }\end{array}$ & 2.81 & 16 & 2.36 & 14 & 3.30 & 30 & 2.95 & 60 \\
\hline
\end{tabular}

Source: PROSEPS Q 2b

electronic media and news portals) were close to ' 3 ' (at least once every three months).

Survey answers seem to confirm the fact that of the three countries, Lithuania is the one in which political scientists most openly engage with the public. Policy scholars in particular see communication with the media as their core activity, and pay less attention to research work and the production of scientific publications; but as we have seen, this openness is due largely to a university-academic framework that is expected to support this type of activity in the name of career development. Political scientists are invited onto television and radio programmes, regularly publish comments on important topics (the adoption of socially important laws, the issue of presidential and governmental reports, corruption scandals), and also provide their assessment of political events on social media.

This contrasts with the situation in Hungary. The presence of political scientists in the written media is particularly weak in Hungary, and this is possibly related to the lack of press freedom in the country. The public media are characterised by a strong degree of political selection, with clear preference being given to the advocates of the current regime. In Croatia, a few political scientists, generally professors from the FPZG, engage with the media; in the main, they are experts on Croatian politics, and sometimes on comparative politics and international relations. Questions of political theory or public policy only rarely find their way into the media. 
The media clearly display an interest in this type of cooperation, which is also of value to the discipline, as it helps the profession, and its sole institutional entity (the FPZG) gain public recognition. Moreover, Croatia's political scientists are not often appointed as policy advisors, and their media participation appears to be a substitute for such in terms of their exercising any potential influence. Of course, media participation also helps improve the public visibility of those political scientists concerned.

Our information regarding how the public sees the presence and work of political scientists, is more limited. In Hungary this 'reflexive engagement' has changed substantially over the past three decades. During the course of democratisation there was initially a genuine interest among the public in political commentary; the new field of interest, the new knowledge and the unprecedented information were appealing. Indeed, political science responded to the public's thirst for knowledge and information. Subsequently, a division began to emerge: political analysts and political scientists became increasingly separated from each other despite the presence of the former group in academia. In the new millennium, new institutional opportunities followed by political events lent this divide positional, and then political, features. Quite a few think tanks were formed which were able to offer new perspectives and more practiceoriented knowledge. The universities were not the ones who met this new demand for the provision of more practical knowledge to society. Increasing political division meant that advocacy think tanks ${ }^{13}$ became advantageously positioned in the media under government surveillance, while in the few remaining media not controlled by government, other experts or other think tanks play this part of the relevance game. Nevertheless, it cannot be said that the public is not aware of this controversial world. A number of well-known publishing houses have brought out political science books written by Hungarian authors. The Political Science Research Centre of the Hungarian Academy of Sciences is particularly active in the field of publication - and as its members focus on current themes, often on concrete empirical bases, this invites media attention, mainly in the online media.

In Croatia, political science books are mainly published by professors from the FPZG, and they can easily find publishers; however, there is almost no public discussion of these works. In Lithuania, political

\footnotetext{
${ }^{13}$ Advocacy think tanks have concrete policy goals and want to influence public opinion accordingly.
} 
scientists generally present their research findings and scientific monographs in the media. Regular surveys of the public's trust in political parties, state institutions and politicians are conducted, and political scientists are invited to comment on the results of these surveys. Major news portals have special sections where policy scholars regularly comment on current policy issues. Unlike politicians, who usually express their party's position on various political issues, political scholars have a reputation as experts who are expected to make objective, impartial assessments. There is widespread trust in the competence and non-political bias of political scientists in Lithuania.

An obvious choice of actor capable of designing a strategy aimed at increasing relevance, would be the national associations (Flinders, 2018, p. 597). However, this is not necessarily what happens, and in any case is not always easy to pursue. For example, the Hungarian association of political scientists has changed from being a politically engaged actor comprising important players in the country's democratic transition, present in person to being a relatively closed, professionally integral organisation, in keeping with the broader view of the profession. This new role has served to distance the profession from politics as such, and more recently has also served to defend the institution against the toxic political atmosphere and potential divisions within the profession. This does help the profession's relevance, and apparently serves the unity thereof. The Croatian Political Science Association was established in 1966, but its activities have always had a low public profile, existing as it has in the shadow of the FPZG. This low public profile can probably be accounted for by the fact that it exists in a small country which does not possess the potential membership needed to create a large organisation dedicated to political science. Nevertheless, in the last couple of years, thanks to a more active leadership and a changing membership due to the increasing number of $\mathrm{PhD}$ graduates involved, the association's profile has been enhanced. Since 2017, the association has held yearly conferences and round tables are being held. Annual conferences of the national associations are a consolidated event in all three countries, and yet these conferences rarely receive any broad attention from the media.

\subsection{Practical Impact}

There can be many aspects to the practical impact of political science: from the personal to the institutional, from the invisible to the visible, and from 
the temporary to the permanent, just to name the more obvious dimensions of this connection between political science and its impact on people and institutions. Here we shall focus on the personal-individual attitudes and activities of political scientists in our respective countries, just as the previous section focused on the different institutional patterns of practiceoriented public engagement in the media.

The main patterns discerned are as follows: a number of politically involved think tanks in Hungary; university-based policy advisory activity in Lithuania and hardly any visible practice-oriented advisory capacity in Croatia. As for the personal impact of political science, an extreme and rarely observed example is that political scientists in person are appointed to important policy-making positions quite often: in Hungary, first the Minister of Culture and now the mayor of Budapest, both belong to the political science academia; in Croatia, government ministers and the mayor of the capital city have political science degrees, and the former President of the Republic had an MSc in political science; in Lithuania, alumni of various political science and public administration programmes, as well as former professors, have been appointed to various important positions in central and municipal government and the Seimas (e.g. the Deputy Ministers minister of Education, Science and Sport; the former Minister of Internal Affairs, etc.). While in countries with more established political science communities this might be a regular practice, in our countries it is reassuring to see that our-new-profession gives credibility to, and sustains, one's career even if it is sometimes difficult to perceive any real impact or pragmatic connection.

Moreover, quite a number of advisors and public officials working in the country's ministries and in other bureaucratic positions, have a political science degree, although again we do not know how they use their particular knowledge, or whether they have a different focus than the majority of those working in such jobs, which are largely held by members of the law profession in all three countries. As for the type of practical advice in the COST survey (Q 13), respondents could choose from the different channels that they tend to use to provide policy advice and/or consulting services. It was found that face-to-face discussion enjoyed prominence, followed by workshops with a non-academic audience, and then by mail/post to the actor or organisation. This indicates a preference for personalised connections (other options included publications, research 
Table 7.6 How often, on average, during the last three years, have you engaged in any of the following advisory activities with policy actors (policymakers, ministry officials, interest groups, political parties, etc.)?

\begin{tabular}{|c|c|c|c|c|c|c|c|c|}
\hline \multirow[t]{2}{*}{ Country } & \multicolumn{2}{|c|}{ Croatia } & \multicolumn{2}{|c|}{ Hungary } & \multicolumn{2}{|c|}{ Lithuania } & \multicolumn{2}{|c|}{ Total } \\
\hline & Mean & $N$ & Mean & $N$ & Mean & $N$ & Mean & $N$ \\
\hline $\begin{array}{l}\text { I provide data and facts about policies } \\
\text { and political phenomena }\end{array}$ & 2.65 & 23 & 2.13 & 62 & 2.76 & 45 & 2.44 & 130 \\
\hline $\begin{array}{l}\text { I analyse and explain the causes and } \\
\text { consequences of policy problems }\end{array}$ & 2.67 & 24 & 2.08 & 62 & 2.93 & 43 & 2.47 & 129 \\
\hline $\begin{array}{l}\text { I evaluate existing, policies, institutional } \\
\text { arrangements, etc. }\end{array}$ & 2.57 & 23 & 1.89 & 61 & 2.73 & 45 & 2.30 & 129 \\
\hline $\begin{array}{l}\text { I offer consultancy services and advice, } \\
\text { and make recommendations on policy } \\
\text { alternatives }\end{array}$ & 2.19 & 21 & 1.92 & 62 & 2.20 & 45 & 2.06 & 128 \\
\hline I make forecasts and/or carry out polls & 1.64 & 22 & 1.52 & 62 & 2.23 & 43 & 1.78 & 127 \\
\hline $\begin{array}{l}\text { I make value-judgements and normative } \\
\text { arguments }\end{array}$ & 2.30 & 23 & 1.68 & 62 & 2.35 & 43 & 2.02 & 128 \\
\hline
\end{tabular}

Source: PROSEPS Q 8

reports, policy briefs, traditional media articles, blog pieces or items posted on social media, training courses and phone connections).

Table 7.6 shows the frequency with which political scientists engage with policy actors in an advisory capacity. This frequency was measured on a scale from 1 (never) to 5 (at least once a week), and shows that political scientists from Lithuania act in an advisory capacity more frequently than their colleagues from Hungary and Croatia. However, the mean value, indicating the level of engagement in advisory activities in all three countries, is closer to either 3 (at least once a year) or 2 (less frequently than once a year).

In this regard, once again Lithuania tops the ranking, while Hungary lags behind in all aspects of advisory activity. In Lithuania, political scientists are invited, as experts, to participate in working groups formed by Parliamentary committees and commissions, the Government, ministries or other public administrative institutions, which prepare draft bills and strategic documents. When ministries and other public administrations tender for policy analysis services and the preparation of public policy recommendations or other expert advice, such tenders are sometimes won by political scientists (they can submit proposals either in their capacity as 
university teachers, or as experts from business or public institutional teams). Some policy scholars have set up public 'think tanks' specialising in public policy analysis and policy advice. Researchers in the field of public administration are also actively involved in conducting in-service training seminars for civil servants. A Public Governance Competence Center has been established by the Ministry of the Interior at Mykolas Romeris University. The Research Council of Lithuania funds research projects aimed at providing practical guidance to public policy makers (many of these projects are funded by general research programmes, although there are also special programmes that fund research into policy recommendations, policy issues and policy evaluation, e.g. the Need Research Projects). For example, in 2020 the Research Council of Lithuania provided funding for research projects aimed at assessing the policy decisions made in response to the COVID-19 pandemic crisis.

\section{TOWARDS RELEVANCE?}

In the introduction we foresaw differences between the country cases examined here. Indeed, despite several similar challenges, a number of important country differences have emerged.

In each country, the legitimacy and the identity of the profession are of paramount importance to how the profession performs in terms of knowledge provision, in societal engagement and in providing pragmatic advice. Legitimacy-related issues in particular are tied closely to the question of relevance: uncertainties and constraints lessen the potential relevance of political science. The formation of the new profession's identity started last in Croatia, paradoxically due, in the main, to the prior existence of a proto-political science during the communist period, and subsequently due to Croatia's belated arrival as a member of the democratic group of countries that emerged after the troubled initial decade following the break up Yugoslavia. In Croatia, the profession aims to ensure its relevance by taking numerous concrete steps mainly in the sphere of education, although the singularity of the institutional framework appears to constitute something of a hindrance. In contrast, the 'open field' inherited from Soviet times in Lithuania would seem to provide political science with considerable relevance. A more open and competitive academic field has given Lithuania the advantage over the other two countries concerned. The singularity of the institution in Croatia cannot be accounted for by the mere size of the country: the population of Croatia is 4 million, 
whereas that of Lithuania is only 2.8 million. Internal initiatives (from within the discipline) together with external policy decisions, seem to contribute to this more competitive, more relevance-oriented environment in Lithuania.

Generally speaking, the policy and political aspects of the achievement of legitimacy, have an impact on the relevance of the profession both in the positive and the negative sense. From the positive perspective, we have found evidence that in Lithuania there are strong policy incentives that encourage both the social engagement and the pragmatic relevance of the profession. On the contrary, when policy and political pressures divide the profession and undermine its credibility, the profession's relevance is seriously harmed, as is the case in Hungary. We should not forget that the pace of institutionalisation also appears to affect the degree to which the profession is able to preserve its relevance: very rapid institutional changes in Hungary have often preceded the profession's internal formative steps and established premature trajectories, as opposed to the slower institutional development witnessed in Lithuania. A north-south divide in terms of relevance, with the north ahead of the south, can also be observed. In this respect, perhaps the aura of a Baltic region with support from Scandinavia plays a role, whereas in the two 'southern' country cases, troubled political developments appear to have left their mark on the profession. The political impact on this divide is clearest in Hungary, although this divide might also be due to the relatively larger size of the community and to an open academic market where the provision of practically relevant services is mostly in the hands of advocacy think tanks. This was particularly clear in the attitudes of the surveyed political scientists: Hungarian political scientists working in the country's universities were more hostile to a practice-oriented political science than their colleagues from Croatia, and even more so from Lithuania. The information provided in this chapter information is based on the authors' own critical expert analysis and the profession's survey results. While the survey answers are the least nuanced of the two sources, we think that the information they provide tends to coincide.

Generally speaking, we can rightly claim that gaining relevance is not a straight road as deviations or even blind alleys may be encountered along the way. If, as we noted in the introduction, relevance means reflecting on, and responding to, societal questions, then becoming relevant requires the profession to constantly adjust. Furthermore, we may also conclude, in general, that the three main aspects of relevance have not been achieved 
to the same level within the same country: one can be more pronounced than the other(s), although we can duly expect a degree of adjustment as the three aspects are basically interconnected and will influence one another. We have also found that the development of relevance is a twoway process: government and university policies act as the external context, while the profession's interests, commitment and ambitions constitute the internal force marking the way forward.

\section{REFERENCES}

Arató, K., \& Tóth, C. (2010). Political Science in Hungary: A Discipline in the Making. In R. Eisfeld \& L. A. Pal (Eds.), Political Science in Central-East Europe: Diversity and Convergence (pp. 149-162). Verlag Barbara Budrich.

Balogh, I. (1999). A politikatudomány Magyarországon az 1990-es években. Az MTA Politikatudományi Bizottságának jelentése a tudomány helyzetéről (Political Science in Hungary in the 1990s. Report of the Political Science Commission of the Hungarian Academy of Sciences). Politikatudományi Szemle, $X(2), 131-142$.

Eisfeld, R. (2011). How Political Science Might Regain Relevance and Obtain an Audience: A Manifesto for the 21st Century. European Political Science, 10, 220-225. https://doi.org/10.1057/eps.49

Flinders, M. (2013). The Tyranny of Relevance and the Art of Translation. Political Studies Review, 11, 149-167.

Flinders, M. (2018). The Future of political science? The politics and Management of the Academic Expectations Gap: Evidence from the UK. European Political Science, 17, 587-600.

Gerring, J. (2015). The Relevance of Relevance. In G. Stoker, B. G. Peters, \& J. Pierre (Eds.), The Relevance of Political Science (pp. 36-49). Palgrave Macmillan.

Jokić, M., Mervar, A., \& Mateljan, S. (2019). The Development of Political Science in Central and Eastern Europe: Bibliometric Perspective, 1996-2013. European Political Science, 18,491-509. https://doi.org/10.1057/ s41304-018-0191-6

Klingemann, H.-D. (2008). Capacities: Political Science in Europe. West European Politics, 31(1-2), 370-396.

Krupavičius, A. (2002). Political Science - Lithuania. In M. Kaase, V. Sparschuh, \& A. Wenninger (Eds.), Three Social Science Disciplines in Central and Eastern Europe: Handbook on Economics, Political Science and Sociology (1989-2001) (pp. 286-287). Informationszentrum Sozialwissenschaften. https://nbnresolving.org/urn:nbn:de:0168-ssoar-281381 
Kwiek, M. (2015). Non-Publishers in European Universities. International Higher Education, 82, 10-11. https://doi.org/10.6017/ihe.2015.82.8866

Linz, J. J., \& Stepan, A. (1996). Problems of Democratic Transition and Consolidation. Johns Hopkins University Press.

Molnár, G., \& Ilonszki, G. (2021). Identity Formation of Political Science in Hungary. European Political Science, 20, 139-158.

Polónyi, P. (2018). A hazai felsőoktatás elmúlt 10 évének néhány gazdasági jellemzője. In G. Kováts \& J. Temesi (Eds.), A magyar felsőoktatás egy évtizede 2008-2017 (A Decade of Hungarian Higher Education 2008-2017) (pp. 79-101). Nemzetközi Felsőoktatási Kutatások Központja.

Rébay, M., \& Kozma, T. (2005). Akkreditáció Magyarországon. In T. Kozma \& M. Rébay (Eds.), Felsőoktatási Akkreditáció Közép-Európában (Accreditation in Higher Education in Central Europe) (pp. 61-74). Új Mandátum.

Ricci, D. (1984). The Tragedy of Political Science. Yale University Press.

Stoker, G. (2010). Blockages on the Road to Relevance: Why has Political Science Failed to Deliver? European Political Science, 9, 72-84.

Stoker, G. (2015). Challenging Three Blockages to Relevance and Politicalscience: The Obvious, the Avoidable and the Thorny. In G. Stoker, B. G. Peters, \& J. Pierre (Eds.), The Relevance of Political Science (pp. 19-35). Palgrave Macmillan.

Teichler, U. (2014). The Academic Profession Between National Characteristics and International Trends. Hungarian Educational Research Journal, 4(1). https://doi.org/10.14413/HERJ2014.01.04

Turk, M., \& Ledić, J. (2016). Between Teaching and Research: Challenges of the Academic Profession in Croatia. Center for Educational Policy Studies Journal, $6(1), 95-111$.

Wilensky, L. H. (1964). The Professionalization of Everyone? American Journal of Sociology, 70(2), 137-158. 
Open Access This chapter is licensed under the terms of the Creative Commons Attribution 4.0 International License (http://creativecommons.org/licenses/ by $/ 4.0 /$ ), which permits use, sharing, adaptation, distribution and reproduction in any medium or format, as long as you give appropriate credit to the original author(s) and the source, provide a link to the Creative Commons licence and indicate if changes were made.

The images or other third party material in this chapter are included in the chapter's Creative Commons licence, unless indicated otherwise in a credit line to the material. If material is not included in the chapter's Creative Commons licence and your intended use is not permitted by statutory regulation or exceeds the permitted use, you will need to obtain permission directly from the copyright holder. 